\title{
Shareholders must vote for climate-change mitigation
}

\section{Investors who are standing idly by as emissions erode the value of their stock could find themselves in court, warn Howard Covington and colleagues.}

$\mathrm{T}$ The largest 500 companies listed on the world's stock markets account for about half of market value and $14 \%$ of global emissions ${ }^{1}$. Steel company ArcelorMittal, utilities firm RWE and oil giant ExxonMobil are among the top ten. All listed companies probably account for roughly onequarter of global emissions. Many of these companies are multinationals, and are not party to the climate deal made in Paris last December, so they could resist or even challenge government plans to reduce emissions.

One way to encourage their cooperation would be for their shareholders to propose and vote for resolutions aimed at increasing or preserving stock value while reducing emissions. Why would shareholders do this? Senior lawyers have concluded that those who manage other people's money have a duty to control for 'material risks' ${ }^{2}$. In finance, that means risks that might trigger a $5 \%$ or more loss in investment value. Climate damage in the future is expected to be one such risk.

Therefore, we (an investment manager, an environmental lawyer and a climate economist) believe that clients and beneficiaries of investment firms might have a legal case to bring against their investors who stand idly by as emissions erode the value of their stock. We are researching and designing such actions.

\section{CASE LAW}

Legal rulings about duties can have far-reaching consequences. In June 2015, a Dutch court found that the government has a duty of care to its citizens to minimize the risk of climate change, and ordered the Dutch government to go beyond its current plan to reduce the country's greenhouse-gas emissions. Pending an appeal hearing, the government is now working towards a $25 \%$ reduction by 2020 .

In another incident last year, a case brought by ClientEarth (where one of us, J.T., works ), the Supreme Court of the United Kingdom found that the British government has a duty to obey its own air-quality laws. Because this case involved the European Court, the rulings of which bind all European Union member states, ClientEarth is preparing a slew of parallel legal actions in other EU countries. Ten such cases were filed in Germany last November. One has already reached judgment, resulting in a court order to the city of Wiesbaden to take all necessary action to clean up

its air. The Chinese judiciary has sought views from ClientEarth on how legal action against emitters could help to address China's air and other pollution challenges.

Systemic climate risk for investors can be expressed in terms of the reduction in value, due to warming this century, of a diversified investment portfolio at a given probability. This is called a climate value at risk. If economic output is expected to be damaged by future warming ${ }^{3,4}$, then portfolio value may be lower than it otherwise would be. Economic damage could accelerate if extreme weather resulting from high levels of warming creates regional instabilities and causes

\section{"Managers could push companies to adopt the goals of the Paris agreement into their constitutions."}

large-scale migration by making populated areas uninhabitable ${ }^{5}$.

Assessment by the investment community of climate value at risk is still at an early stage $^{6}$. Initial estimates point to a value at risk of $10 \%$ or so at probabilities of loss that are within the range typically used in financial management. The total value of the shares listed on the world's equity markets is around US $\$ 70$ trillion, suggesting that the potential loss from a plausible worst case is currently roughly $\$ 7$ trillion. This is a measure of the systemic climate risk to the world's equity markets.

\section{MANAGING RISK}

This risk exceeds the legal test of materiality and should be too large to ignore. In practice, most investors neglect it entirely.

What should money managers be doing about systemic climate risk? Because it arises from damage to the economy as a whole, the risk cannot be reduced by hedging investments or by limiting exposure to particular assets. Investors should actively encourage the companies they own to reduce emissions, for example by urging profitable investment in energy efficiency or emissions-reducing changes to processes and by discouraging risky capital expenditure on fossil-fuel exploration and production.

Better still, managers could push companies to adopt the goals of the Paris agreement into their constitutions and to publish business plans for how they will deal with the transition to a zero-carbon economy.

A few forward-looking investors are already acting in this way and are beginning to have an effect. Last year, CCLA, a British investment firm, led the filing of shareholder resolutions requiring greater emissions disclosure from Shell and BP. This was followed by BHP Billiton, a mining company, responding to concerned investors by producing an analysis of how its business would operate in an emissions-constrained world. These are useful steps, but they are small.

To produce a wholesale change in attitude, a court ruling on the obligations of fiduciary investors to control systemic climate risk will probably be needed. Because of the uncertainties in estimating future climate damage, this will not be an easy case to bring. But we anticipate that such a case will ultimately succeed. We are seeking more and better quantitative assessments of systemic climate risk and, in particular, the risk to investment portfolios, to help to clarify the relevant obligations.

The Paris agreement was a diplomatic triumph. But it will remain largely voluntary until countries translate the promises into their own legal systems. Then it will take constant pressure to ensure implementation and prevent backsliding. Investors will play a major part, either voluntarily or because they will be forced by the courts to meet their legal obligations to manage climate risk. .

Howard Covington is chair of the Alan Turing Institute in London. James Thornton is chief executive of ClientEarth, an environmental-law firm in London. Cameron Hepburn is professor of environmental economics at the University of Oxford, UK.

e-mail:hcovington@turing.ac.uk

1. Moorhead, J. \& Nixon, T. Global 500 Greenhouse Gases Performance 2010-2013: 2014 Report on Trends (Thomson Reuters, 2014).

2. Law Commission. Fiduciary Duties of Investment Intermediaries (UK Law Commission, 2014).

3. Burke, M., Hsiang, S. M. \& Miguel, E. et al. Nature 527, 235-239 (2015).

4. Dietz, S. \& Stern, N. Econ. J. 125, 574-602 (2015)

5. Pal, J. S. \& Eltahir, E. A. B. Nature Clim. Change 26, 197-200 (2016).

6. Economist Intelligence Unit. The Cost of Inaction: Recognising the Value at Risk from Climate Change (Economist Intelligence Unit, 2015). 